\title{
Increasing Household Protein Consumption Through Minilivestock Production In Nigeria
}

\author{
By
}

\section{E. Barwa}

\begin{abstract}
Mini-livestock production can be a major contributor of a more balanced diet for both rural and urban settlements. The attributes of mini-livestock gives it the potential of increasing household protein consumption as well as being a source of income. Mini-livestock production can be practiced in rural and urban settlements considering its small size, low-cost management requirement and low capital investment. Mini-livestock production is sustainable and can be handled conveniently by women and children. The aim of this paper is to draw out the potentials of mini-livestock production and the need to harness these potentials in increasing household animal protein consumption in rural and urban households.
\end{abstract}

\section{Introduction}

Animal protein intake is quite low in developing than in developed countries. The FAO recommends a minimum of $70 \mathrm{~g}$ of protein daily per caput, out of which at least $35 \mathrm{~g}(50 \%)$ should come from animal proteins, but the average Nigerian consumes less than $10 \mathrm{~g}$ of protein with only $3.2 \mathrm{~g}$ of this amount from animal protein (Abu et al, 2008).Over the years, efforts and concentrations has been put on developing the conventional meat sources (cattle, sheep, pig, goat, poultry) to meet the animal protein requirement to no avail. The FAO raised an alarm of the animal protein deficiency of Nigerians (Akinusi,2000).

Lyon (2000) observed gradual shift from the production, consumption of conventional animal protein sources (cattle, sheep, swine, goat, poultry) to a class of livestock referred to as 'mini-livestock', 'micro- livestock' or 'unconventional livestock'. Hardouin and Stiévenart (1993) reported that the interested scientific community decided in 1992 that only the term mini-livestock (mini means leverage, in French ) should be used when speaking of animals such as edible rodent, giant snails, frogs, manure worms, insects and similar animals when used for food, as animal feed or as source of income. Mini-livestock encompasses small indigenous vertebrates and invertebrates which can be produced on a sustainable basis for food, animal feed and as a source of income (Hardouin et al, 2003).

With the shortage of animal protein, nutritionists are now interested in prolific, good converters of feed to flesh and short production cycle animals (Isaac et al, 2010).Considering the problems of human protein malnutrition, Devendra (1976) is of the opinion that a well planned research programme closely linked to improved husbandry practices of micro-livestock can greatly enhance the already existing contribution of micro-livestock to combating animal protein deficiency. Vietmeyer (1984) considers microlivestock such as rabbit, guinea pig, grasscutters, rats, iguana and pigeons as a rapid means of obtaining animal proteins.

\section{Attributes of mini-livestock as a potential animal protein source}

Mini-livestock production can be a major contributor of a more balanced diet for both rural and urban settlements. The attributes of minilivestock gives it the potential of contributing significantly to food security and meeting up the recommended dietary animal protein intake. Its small indigenous and flexible nature makes it a suitable livestock production that can be handle by women and children (Hardouin et al, 2003). Mini-livestock production can be practiced in rural and urban settlements considering its small size, low-cost management requirement and low capital investment.

Mini-livestock such as rabbits, quails, grasscutters, pigeons etc are characterized by short generation intervals, large number of offspring and fast growth of young and these are the attributes that make their use particularly important in the context of smallholder farming 
(Peters, 1987).The high reproduction capacity of mini-livestock reduces the proportional energy requirement of the reproduction unit, resulting in a more efficient utilization of nutrients in the production process, thus improving resources utilization and small scale production system or marginal environments. (Peters, 1987).

Mini-livestock such as guinea pig, rabbits, grasscutters have the ability to digest almost any form of edible green stuff, ranging from coarse grasses to roughages and household scraps (GTZ, 1985, Müller-Heye, 1984, Asibey, 1974). Similarly, mini-livestock such as edible snails have the ability to utilize decaying materials, thus can be used to achieve more efficient recycling of nutrients. (Elmshie, 1982, 1984). Mini-livestock such as quails, pigeons, snail feed consumption is minute. The small size of this mini-livestock minimizes wastages. Animals slaughtered can be consumed immediately particularly in places where refrigeration is not available (Vietmeyer 1984, Hodasi, 1984).These mini-livestock do not compete with man for food, and also do not compete for space, are easy to house and manage, they can easily be incorporated into mixed production system to expand the available food resource base.

\section{The potential of mini-livestock in meeting animal protein demand.}

\section{Rabbit}

According to Abu et al (2008), the rabbit appears to be the most sustainable means of producing high quality animal protein for the expanding populations of the lesser developing countries like Nigeria. It is small-bodied sized (2.5 $5.4 \mathrm{Kg}$ ), has a short generation interval (6 months), rapid growth rate, genetic diversity, large litter size, ability to utilize forage and agricultural by-products, and adaptation over a wide range of ecological environment. In addition, it is a affordable and its management requirements are low-cost. Rabbit production can provide the impoverished urban population and the resource-poor rural dwellers the opportunity to meet part of their total protein intake and earn additional income. A buck and 5 does are capable for providing the animal protein requirement for an average family.

\section{Guinea Pig}

The guinea pig is a rodent and considered a very promising 'micro-livestock' species for rural development due to the fact that it requires little capital, equipment, space and labour and provides an inexpensive, readily available high quality meat (Nuwanyakpa et al 1997). The guinea pig has been known to contribute to the alleviation of protein deficiency in the diets of people in developing countries. The guinea pig attains maturity as early as 1 month for the female, has a lifespan of 6-8 years, however maximum productivity for females according to Hum and Roca (1982) is between 3-18 months. Gestation length is 70 days, litter size varies between 1-6. Females like the rabbit can conceive shortly after parturition thus five parturitions per year is possible. Ngoupayou et al (1995) reported an average interval of 65 days. Like the rabbits, guinea pigs can ingest and utilize large quantities of high energy fibrous type foods such as freshly cut, palatable forages. Research work in Cameroun, shows that raising of guinea pigs is one way for farmers to inexpensively produce meat for home consumption or for sale (Nuwanyakpa et al, 1997). With 20 breeding females and 2 males, a family of 6 can be provided with a year round adequate supply of nutritious meat (NRC, 1991). Guinea pig is one of the easiest and cheapest source of animal protein to the populace(Ikani, 2002)

\section{Grasscutter}

The grasscutter is also a rodent (Thryonomys swinderrianus). Its presence has been observed in the semi-arid sahel as in the great equatorial forest belt (American National Research Council,1991). The grasscutter feeds on a wide range of plants from grasses(penisetum, sugar cane, maize) herbaceous legumes (stylosanthes peuraria) to tuber crops like sweet potatoes and cassava. It also feeds on cereals like rice and legumes like groundnut. It has been observed that rabbits only eat leaves of grasses while grasscutters eat the stems, hence grasscutters and rabbits can constitute a perfected integrated system,for the complete utilization of local grasses (Finzi, 2000). The grasscutter weighs between $5-8 \mathrm{~kg}$, female attains maturity at 5 months and males at 7 months, gestation period is 5 months (152 days), with an average litter size of 5 . Production life span is 5 years. The average dressing percentage is $65 \%$, if head and entails are included it could reach $85 \%$. With intensive management 2 litters/ year is possible. Backyard rearing of grasscutter in rural or urban settlement( starting with a male and 5 females) 
has the capacity to provide adequate animal protein of an average family year round.

Quail

Quails are small-bodied birds. The most common is the genus Coturnix coturnix. The most widely spread and commercially produced is Coturnix coturnix japonica (Japanese quail). This was introduced into the country, courtesy of N.V.R.I., Vom. Quails are reared for meat and eggs. This bird has the potential of meeting the animal protein need of households both in rural and urban settlement. At maturity, the males weigh $100-140 \mathrm{~g}$ and females 120-160 g. Compared to most poultry and other farm animals they require smaller space $\left(70\right.$ birds $\left./ \mathrm{m}^{2}\right)$ consume lower quantity of feed (20-25 g) are resistant to most poultry diseases including Newcastle disease. In addition, quails have a short generation interval, early maturity(6 weeks), fast growth rate, high egg production (250-300 eggs/year) and have an incubation period of 17-18 days. The meat and eggs of quails are of high biological value (low in cholesterol).Quail production is easy to learn and practice and can be started with little money. These easy care birds can be housed in small, simple inexpensive cages. It is said that about 20 quails are sufficient to keep an average family in eggs year-round (NRC, 1991b).

\section{Pigeons}

Pigeons can be reared in rural and urban settlements. With an appropriate shelter, any family can raise pigeons. Shelter can be made from no-cost recycled materials. The cost can be only that of few grains offered to the birds to get them accustomed to the place during confinement. However improved feeding and management will enhance production. Pigeons mature at about 6 months and lay eggs each time. Incubation period is 17-18 days. The young ones called squabs are ready for harvesting (meat) between 26-30 after hatching weighing about 250-400g. 2 weeks after hatching, the pigeons (adults) are ready to lay again. In other words, a pair of pigeons is capable of producing 12 marketable squabs in a year i.e brooding about 6 times in a year. In other words 5 pairs (10 pigeons) are capable of providing about $3 \mathrm{~kg}$ liveweight of meat per month at minimum cost. The pigeons have a life span of about 5 years. There is need to harness and maximize the potential of this mini-livestock in meeting the animal protein need of the Nigerian populace.
Poultry

Indigenous chicken production is practiced by over $90 \%$ of rural households in Nigeria on a free range system. These birds contribute over $60 \%$ of poultry production in Nigeria. Local chicken reach point of lay at about 7 months, weighing about $1.2 \mathrm{~kg}$, lay about 12 eggs per clutch, incubate for 21 days. These birds are mostly uncared for and susceptible to many diseases especially Newcastle disease. Despite the fact that most rural households rear poultry, this is not enough to meet the animal protein demand. Through simple technology with better management indigenous poultry production could be improved thus increasing animal protein. Studies from National Animal Production Research Institute indicate that local chickens irrespective of age can be adequately protected against Newcastle Disease. They should be vaccinated around September- October prior to commencement of Newcastle Disease outbreaks. In addition, upgrading the local birds with improved cockerels showed over 50\% improvement on growth rate, total egg number and size. Also weaning (removal of chicks from hen within 2-3 days) and artificial brooding minimizes losses due to predators as well as early return to lay by the hen.

\section{Snail}

Snails are invertebrates with soft bodies that are covered with hard Calcareous shells. Snails belong to the phylum of animals known as mollusca. Some other members of the mollusca are slugs, mussels and oysters. Many species of edible land snails are recognized but the popular species of economic interest is the West Africa giant snails. Archachatina marginata and Achatina achatina.

Snail meat is high in protein . In addition, recent studies indicated that the glandular substances from edible snails cause agglutination of certain bacteria, which could be of value against a variety of ailments including whooping cough. In folk medicine, the bluish liquid obtained when the meat has been removed from the shell is believed to be good for infant's development. It is believed in some quarters that snail meat contains pharmacological properties of value in counteracting high blood pressure.

In Nigeria snails are ordinarily collected from the wild. snail production like other mini-livestock have the potential of meeting up the animal 
protein demand. the genus Archachatina marginata weighs about $150-200 \mathrm{~g}$ or more at maturity. They grow to full size in 24 months if well fed. They lay about 5-10 eggs 4-8 times each growing season. The Achatina achatina weighs between 100- 400g, lays from 100- 300 eggs one or two times each growing season. The eggs hatch in 30 days . Life expectancy of snails is 5-6 years. Soil is a major part of a snails' habitat and soil composition, water content and texture, calcium content are important factors to consider in site selection. Snails feed mainly on green leaves, fruits, tubers and flowers.

\section{Conclusion}

Mini-livestock production has the potential to increase household animal protein consumption as well as being a source of income. It is sustainable and can be handled conveniently by women and children. There is enough information on mini-livestock production even though further research need to be intensified to improve on the already existing production levels.

There is need to harness the potential of this group of animals through enlightenment campaigns, promotional programmes by both government and non-governmental organizations.

\section{References}

Abu, O. A., Onifade, A. A., Abanikannda, O. T. F. and Obiyan, R.I.(2008) Status and Promotional

strategies for Rabbit production in Nigeria. $9^{\text {th }}$ World Rabbit congress, June 10-13, 2008, Verona,

Italy.

Akinnusi, O. (2000) Snail rearing - A case study of Abeokuta, Ogun state. In: Proceedings of $5^{\text {th }}$ Annual

conference of Animal Science Association of Nigeria, Port Harcourt, Nigeria.

Asibey, E. O. A.(1974) The grasscutter (Thryonomys swinderianus) in Ghana. Symp Zool. Soc. (London)

34: $161-170$

Chinaka, C. and Wilson, E. R. (1995) Snail production techniques in Nigeria. Extension Bulletin No. 108, Forestry Series No. 12

Cobbinah, J.R.( ) Snail farming in West Africa: A practical guide. CTA
Devendra, C. (1976) Goat production in the tropics. Common Wealth Agric. Bureau. 30-32.

Elmshie, L. J. (1982) Snail and snail farming. World Animal Review. 41:20-26

Elmshie, L. J. (1984) Edible snails. In: I. L. Mason(ed), Evaluation of domesticated animals. Longman

Group limited, Harlow, Essex, UK.

Fayenuwo, J. O.;Akande, M.; Taiwo, A.A. Adebayo, A. O.;Saka, J. O. ;Lawal, B. O.; Tiamiyu, A.K. and

Oyekan, P. O.(2003). Guidelines for Grasscutter rearing. Technical Bulletin, IAR \& T, OAU, Moor plantation.

Finzi, A. (2000). Integrated backyard systems. Rabbit and Guinea Pig Unconventional Rearing

Experimental Centre, Animal Production Department, University of Tuscia, Italy, FAO,2000.

GTZ (Gesselschaft für Technische Zusammenarbeit)(1985) A compendium of Rabbit production.

Schriftenreiheder GTZ, Nr.169. GTZ, Eschborn, FRG.

Hardouin, J. (1995). Mini-livestock: from gathering to controlled production. Biodiversity conservation 4:220-232

Hardouin, J. and Stievenart, C. (1993)Invertebrates (mini-livestock).

Proceedings of a seminar, Philippines.224p.

Hardouin, J., Thys, E.,Joiris, V. and Fielding, D. (2003) Mini-livestock breeding with indigenous species

in the tropics. Livestock Research for Rural Development (15) 4.

Hodasi, J. K. M.(1984) Some observations on the Edible giant land snails of West Africa. World Animal

Review 52:24-28.

Ikani, I. E.(2002) Poverty Alleviation in Rural Nigeria: The role of Guinea pig farming. NAQAS

Newsletter Volume 2, No. 1.

Isaac, L. J.;Eko, P. M.; Ekpo, J. S.;Ekanem, E. and Essien ,G. B. (2010).Effects of Breed on performance

of Rabbit in feed. Proc. of the $35^{\text {th }}$ conference of Nigerian Society for Animal Production, 14-17 March, 2010, University of Ibadan, Nigeria. 
Jokthan,G. E.; Olugbemi, T. S.; Jolomi, A.(2007). The nutritive value of some microlivestock and their role in human nutrition. Savannah journal of Agriculture, Vol.2, No 1, June 2007.

Lyon, W. F.(2000) Insects as Human food. http://www.ojionline.osu-edu.

Muller-Heye, B. (1984) Guinea pig or Cuy. In:I. L. Mason (ed), Evaluation of domesticated animals.

Longman Group ltd, Harlow, Essex, UK.

N.R.C.(1991a) Micro-livestock. Chapter 20. Guinea pig. National Academy Press, Washington D. C.

N.R.C.(1991b) Micro-livestock. Chapter 11. Guinea pig. National Academy Press, Washington D. C.

Nuwanyakpa, M.;Lukefahr, S. D.;Gudahl, D.,Ngoupayou, J. D.(1997a). The current stage and future

prospects of guinea pig production under smallholder conditions in West Africa: Global

overview. Livestock Research for Rural Development,Vol. 9,No.5,Nov 1997

Nuwanyakpa, M.;Lukefahr, S. D.;Gudahl, D.,Ngoupayou, J. D.(1997b). The current stage and future

prospects of guinea pig production under smallholder conditions in West Africa: Cameroun case.

Livestock Research for Rural Development,Vol. 9,No.5,Nov 1997

Peters, K. J.(1987) Unconventional livestock:Classification and potential uses. ILCA Bulletin, 27,April 1987.

Vietmeyer,N. (1984) Livestock for the landless. Ceres No. 98(No 17, No 2):43-46 